\title{
An Investigation of Risks Factors affect to Housing Loan's Processes in Thailand Commercial Banks
}

\author{
Sukulpat Khumpaisal \\ Innovative Real Estate Development Programme \\ Faculty of Architecture and Planning, \\ Thammasat University, Pathumtani, Thailand \\ Wiparut Meechai \\ Innovative Real Estate Development Programme \\ Faculty of Architecture and Planning \\ Thammasat University, Pathumtani, Thailand \\ Katkate Bunnag \\ Government Pension Funds (GPF) \\ Bangkok, Thailand
}

\begin{abstract}
This paper presents an investigation of the risk factors that affect to the housing loan's approval processes in Thailand's 5 largest commercial banks, with the largest amount of housing loan' Non Performing Loan (NPL). The data, obtained from 15 selected interviewees from 5 largest Thailand commercial banks, has been summarised, reported, and analysed by the qualitative content analysis technique. The interviewees include Mortgage Sales (Housing loan), Retail Credit Analyst and Credit Risk Analyst. The instruments, derived from both qualitative and quantitative approaches, to assess the borrowers' credit risk were also formulated in this paper. The results from this study can be used as a benchmark for other Thai financial institutions in order to improve the housing loan's approval processes.
\end{abstract}

Keywords: Credit risks; housing loan; Thailand Commercial Bank; 5Cs indicators; Risk Assessment.

\section{INTRODUCTION}

The property buyers typically require a large sum of money to buy or possess their houses. They typically acquire the fund by borrowing from commercial banks. However, they may have some difficulty in repaying the loan, due to their own capability to repay loan, their personal monetary terms, etc. [1].On the other hand, the banks also hold the risk of losing the amount loaned to the borrowers, which is basically regarded as "Credit risk" [2]. IMF [3] defined the Credit risk as the potential that a bank's borrower or counterparty fails to meet its obligations in repaying the loan borrowed from the financial institutions ("banks"). Thus, the banks need to manage the credit risks in their portfolio both at the individual borrower and transactional level, as well as to consider the linkage between credit risks and other types of risk. This is because these are criteria to assess the success/failure any banking lending activities [3]

The paper starts with exploring the credit risk analysis methods currently used by Thai commercial banks in the housing loan lending process, following by the empirical results gathered from the selected Thai commercial banks' representatives. This process is to find out the risks that have the most influential impact on the housing loan processes. 


\section{NON PERFORMING LOAN (NPL) OF HOUSING LOAN IN THAILAND BANKING SECTOR}

IMF's Compilation Guide on Financial Soundness Indicators 2004, defines Non Performing Loan (NPL) as a loan of which the payments of interest and/or principal are past due by 90 days or more, or interest payments equal to or greater than 90 days have been capitalised, refinanced, or delayed by agreement, or payments are less than 90 days overdue due to some reasons such as borrower's bankruptcy and cannot make his/her payment in full [4]. Bank of Thailand reports that the amount of NPL in Thailand Housing sector rose to 7.6\% in 2016 which is high relatively to the history since Tom Yum Kung crisis in 1997. This paper applies the IMF's NPL definition to identify the housing loan associated within the housing and real estate sector of 5 largest Thai commercial banks, that past due by 90 days or more, and the borrowers did not have capability to repay loan, within the condition of loan acquisition. We focus extensively on this sector, because the real estate sector, particularly housing or residential, is the real productive sector which also drives the dynamic of other industries, and stabilise the whole national economic system [5]. In order to protect the business confidentiality and the ethics of the banks used as case studies, the authors, herein, named those bank as "Bank A, Bank B, Bank C, Bank D and Bank E", respectively.

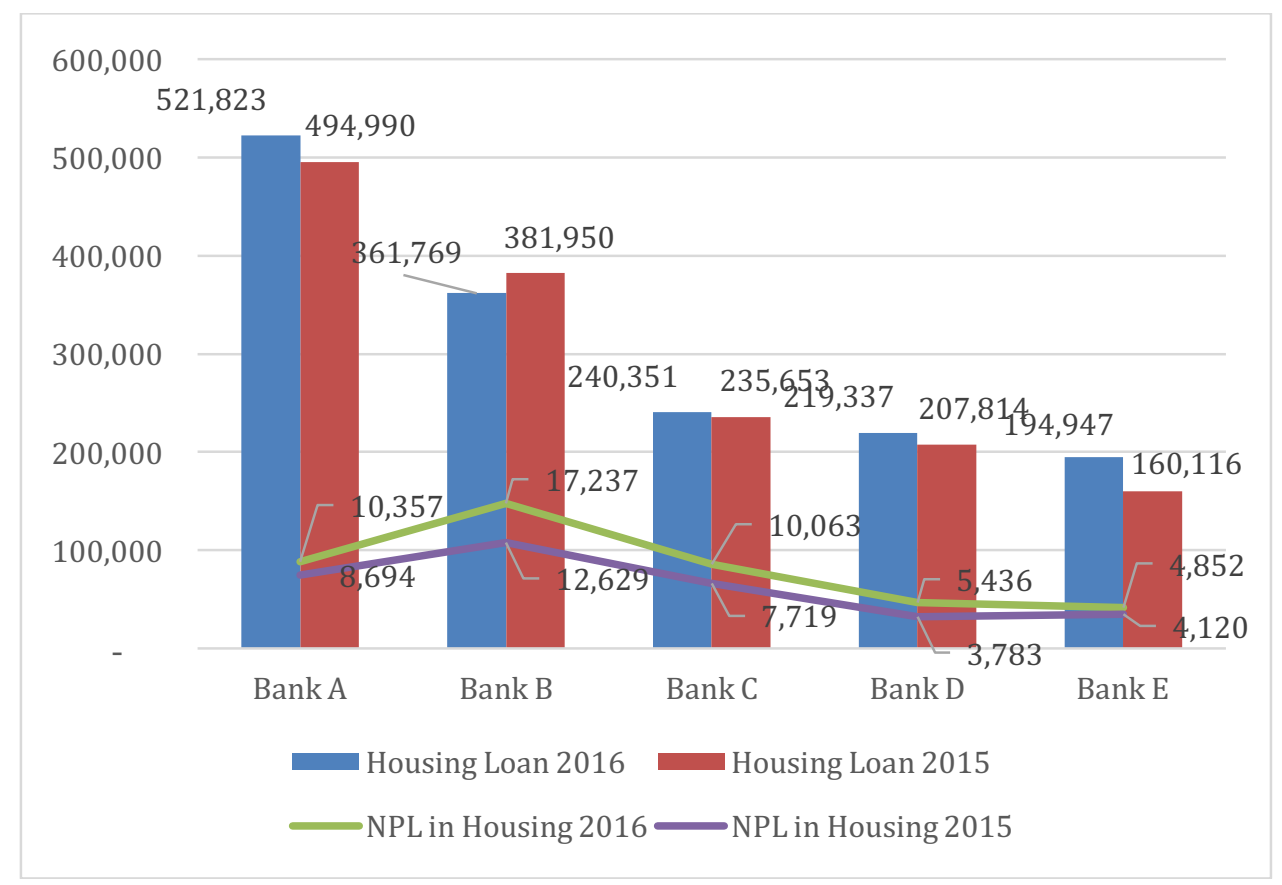

Figure 1 The amount of NPL of 5 largest Thai Commercial Banks (million baht) 2015-2016 (YOY)

The amounts of NPL in housing sector may have less significant while comparing with overall housing loans of those Thai commercial banks (See figure 1), it is summarised that average percentage of NPL on housing loan of 5 largest banks at fiscal year-end 2015 is $2.55 \%$ and $3.18 \%$ in fiscal year-end 2016 respectively [6]. However, BOT also predicts that the cumulative percentages of NPL in housing loan sector slightly increase in the following years. (see Table 1) [7] 
Table 1 : Portions of NPL housing loan of Thailand Largest 5 Commercial Banks

\begin{tabular}{|l|c|c|c|c|c|}
\hline & Bank A & Bank B & Bank C & Bank D & Bank E \\
\hline $\begin{array}{l}\text { NPL of Housing Loan } \\
2015\end{array}$ & $8,694.00$ & $12,629.07$ & $7,719.00$ & $3,783.00$ & $4,120.00$ \\
\hline 2015 Housing Loan & $494,990.00$ & $381,950.33$ & $235,653.00$ & $207,814.00$ & $160,116.00$ \\
\hline \% of NPL /Housing Loan & $1.76 \%$ & $3.31 \%$ & $3.28 \%$ & $1.82 \%$ & $2.57 \%$ \\
\hline $\begin{array}{l}\text { NPL of Housing Loan } \\
2016\end{array}$ & $10,357.00$ & $17,236.52$ & $10,063.00$ & $5,436.00$ & $4,852.00$ \\
\hline 2016 Housing Loan & $521,823.00$ & $361,769.40$ & $240,351.00$ & $219,337.00$ & $194,947.00$ \\
\hline \% of NPL /Housing Loan & $1.98 \%$ & $4.76 \%$ & $4.19 \%$ & $2.48 \%$ & $2.49 \%$ \\
\hline
\end{tabular}

\section{THE CURRENT PRACTICE: CREDIT RATING SCORES}

Thai Commercial banks currently employ the qualitative methods to evaluate the borrowers' credit risk, typically grounded on the 5Cs' principles, comprising Character of borrower, Capacity in repaying load, Collateral, Capital, and Conditions of lending contract. In this regard, 5Cs' were defined by [8], [9] as:

- Character or the borrower's personal profiles, behaviour in repaying loan, the pass records of loan borrowings etc. It is divided into 2 attributes as (1) Borrower's personal profiles that include borrower's behaviour, family, ages, personal integrity, or the borrowers' reputations, and (2) Special capabilities of borrowers such as experience, personal specialty, wisdom or legal responsibilities [7].

- Capacity is regarded as the borrower's abilities to find a source of fund to repay loans, in terms of personal loan. It also depends on the borrowers' character [3].

- Capital generally measured by Debt / equity ratio, or the ratio of the borrower's equity on debts. This ratio helps the analysts to understand the borrowers' financial situation [7], [10].

- Collateral including properties, land, commodities or other assets pledged as security for repayment of a loan, to be forfeited in the event of a default [11]. Collateral is property or an object of value, which a credit grantor can take and sell in case of default. A secured loan is the loan which collateral is required as security to the lender, whereas, unsecured loan is one where there is no collateral required; just an agreement to repay what is owed as agreed [8].

- Conditions means the factors often are considered by the analyst when assessing the creditworthiness of the borrowers. These also include economic conditions affecting a borrower's ability to repay, such as unemployment, seasonal employment [9]

Thailand commercial banks may apply whether the traditional financial ratios, such as Return on Investment (ROI), Return on Asset (ROA), or debt and coverage ratios such as Short-term Solvency Ratios and Capitalisation Rate [3], [9], [13] to quantify the borrowers' risks. Although these methods are simple, but they normally depend on the credit analyst's experiences, and the past performance of the borrower, in this regard, these may cause more subjectivity and bias to the credit analysts or other users. This paper intends to investigate the related factors that influence a decision maker for analysing risks, as well as prioritises the seriousness of risks associated in the housing loan approving processes.

\section{RESEARCH METHODOLOGIES}

This paper started with an extensive literature review on the current credit risk assessment criteria (5 Cs), popularly used by Thai commercial banks. This review included the sub-criteria that need to consider on the capabilities of the borrowers when applying for the housing loans. The authors developed the research variables and data collection instruments, based on the criteria found during the literature review processes. The structured interviews were used to 
collect in-depth information from the selected 15 interviewees from the 5 largest Thai Commercial banks, which consist of large amount of housing loans, and Non Performing Loan (NPL).There were anonymously labelled as Bank "A", Bank "B", Bank "C", Bank "D", and Bank "E", respectively. Three interviewees were selected from each aforementioned bank, by considering their roles and responsibilities in making decision on the housing loan. The banks representatives comprise: (1) 3 Mortgage sales (housing loan) (2) 3 Retail credit analysts, and (3) 3 Credit risk analysts (see Table 2 ).

Table 2 : Interviewees Schedule

\begin{tabular}{|c|c|c|c|c|c|}
\hline \multirow{2}{*}{ Banks } & \multicolumn{5}{|c|}{ Representatives from } \\
\hline & Bank A & Bank B & Bank C & Bank D & Bank E \\
\hline $\begin{array}{l}\text { Percentage of NPL in the housing } \\
\text { loan sector }\end{array}$ & $1.50-2.00$ & $1.50-2.00$ & $2.00-3.00$ & $2.00-3.00$ & $1.50-2.00$ \\
\hline \multicolumn{6}{|c|}{ Position and working experiences (years) } \\
\hline Position & Bank A & Bank B & Bank C & Bank D & Bank E \\
\hline Manager (Mortgage sales : MS) & 24 & 11 & 22 & 20 & 15 \\
\hline $\begin{array}{l}\text { Manager (Retail credit analysis : } \\
\text { RCA) }\end{array}$ & 20 & 22 & 24 & 20 & 25 \\
\hline Manager (Credit risk analysis: CRA) & 21 & 33 & 20 & 24 & 21 \\
\hline
\end{tabular}

To facilitate the interviewing process, the authors develop the interview records and the ranking table, to gather the informants' opinion $s$ and the rank of $5 \mathrm{Cs}$ ' seriousness into the percentage (\%), followed by the descriptive statistics to prioritise the level of 5 Cs' factors. The qualitative content analysis [XXX] was then used to interpret, analyse, and synthesise all data gathered from all informants. This is in order to explore the risk considerations and other related factors to credit risk. The final outcome of this paper is comprehensive assessment criteria to assess the Housing loans' credit risk. Therefore, the overall research stage is summarised in figure 2 (See Figure 2)

The data collection and analysis processes were divided into 2 phases. In the first phase, fifteen informants of the relevant department, relating to approving housing loan were interviewed, to collect their opinions towards the degree of $6 \mathrm{Cs}$ ' impact, as well as the ranking of impacts of 5Cs (see Table 3). In the second phase, they described the detail of the considered factors relating to credit risk while lending the housing loan. The factors from this phase were summarised to found the comprehensive 5Cs criteria to investigate the impact of each risk associated in the housing loan approval. 


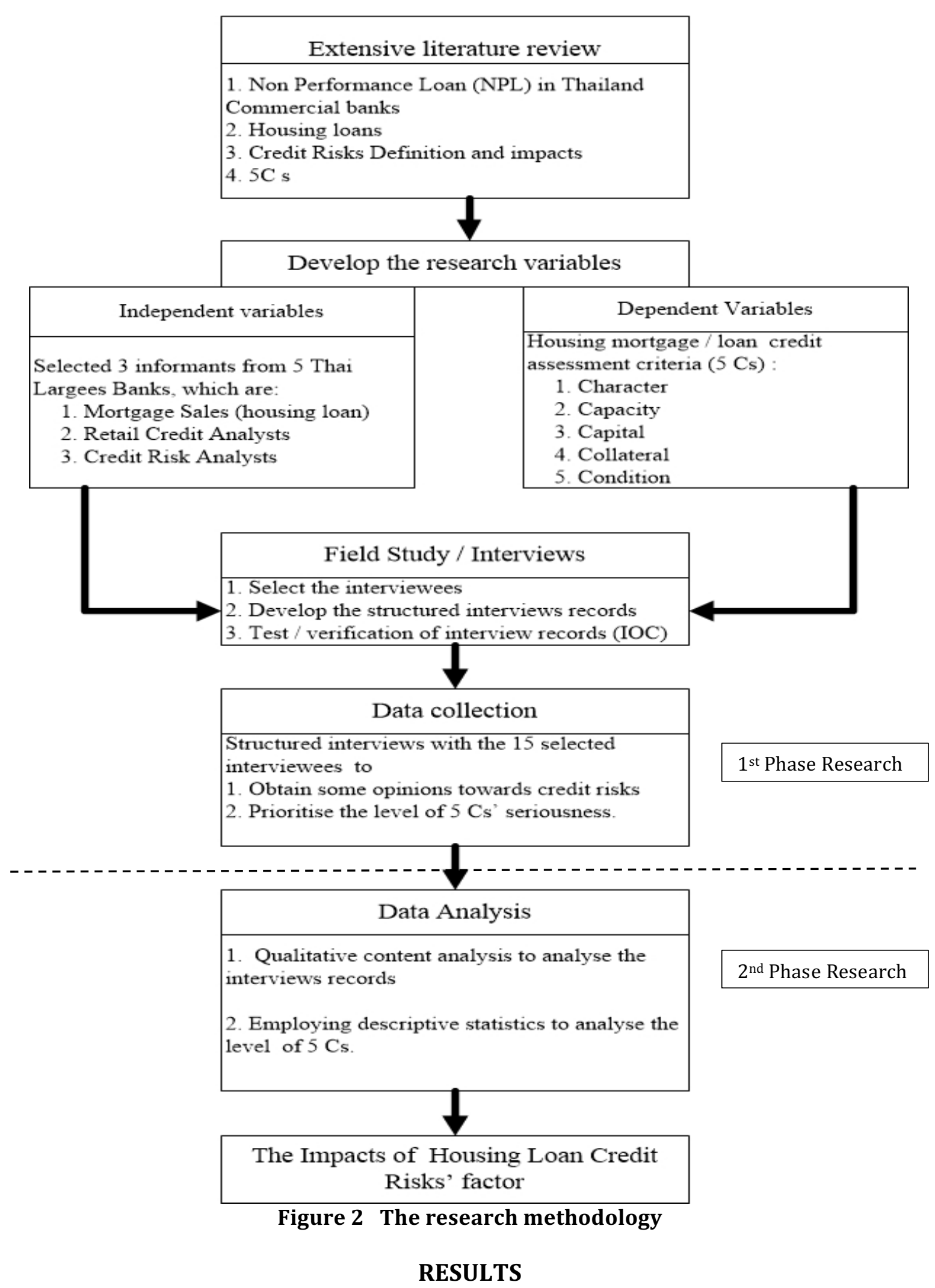

\section{First Phase results}

\section{RESULTS}

The interviewees in the aforesaid 3 groups states their weights of $5 \mathrm{Cs}$ ' level of consequences. Then, the descriptive statistics, such as the percentages of total for each rank and the averages, were used to calculate the percentage of each group, before combining all results to prioritise the degree of 5 Cs' seriousness. 
According to Table 3, the groups of MS and CRA stated that the Character factor contains the highest impact among other 5Cs, with an average of $35.67 \%$, whilst RCA weighed this factor as the second priority. Capacity becomes the second highest impact factor, as the average weight of $34 \%$, followed by the Collateral factor, with the average of $10.67 \%$, Capital at $10.33 \%$, which is slightly higher than Condition of $9.33 \%$. This phase findings confirms [5], [3], and [4] that Character factor contains the highest impact on risk assessment to overall housing loan approving process since this Character factor covers the necessary sub-criteria such as personal profiles of borrowers, loan repayment records and borrowers' financial status, etc. The authors also investigate the sub-criteria that shall be included in this Character factor, as well as in the other four factors in 5Cs in the second phase of this study.

Table 3 : The Results of 5CS Weighted (WT.) And Rank of 5CS Seriousness

\begin{tabular}{|c|c|c|c|c|c|c|c|c|}
\hline \multirow[t]{2}{*}{$\begin{array}{l}\mathrm{CS} \\
\text { Priority }\end{array}$} & \multicolumn{2}{|c|}{$\begin{array}{l}\text { Mortgage Sale } \\
\text { (MS) }\end{array}$} & \multicolumn{2}{|c|}{$\begin{array}{l}\text { Retail Credit Analyst } \\
\text { (RCA }\end{array}$} & \multicolumn{2}{|c|}{$\begin{array}{l}\text { Credit Risk Analysis } \\
\text { (CRA) }\end{array}$} & \multirow[t]{2}{*}{$\begin{array}{l}\text { Average } \\
\text { Weighted }\end{array}$} & \multirow[t]{2}{*}{ Rank } \\
\hline & $\begin{array}{l}\text { Wt. } \\
(\%)\end{array}$ & $\begin{array}{l}\text { Rank in } \\
\text { group }\end{array}$ & $\begin{array}{l}\text { Wt. } \\
(\%)\end{array}$ & $\begin{array}{l}\text { Rank in } \\
\text { group }\end{array}$ & $\begin{array}{l}\text { Wt. } \\
(\%)\end{array}$ & $\begin{array}{l}\text { Rank in } \\
\text { group }\end{array}$ & & \\
\hline Character & 38 & 1 & 29 & 2 & 40 & 1 & 35.67 & 1 \\
\hline Capacity & 32 & 2 & 39 & 1 & 31 & 2 & 34.00 & 2 \\
\hline Collateral & 9 & 5 & 12 & 3 & 11 & 4 & 10.67 & 3 \\
\hline Capital & 10 & 4 & 9 & 5 & 12 & 3 & 10.33 & 4 \\
\hline Condition & 11 & 3 & 11 & 4 & 6 & 5 & 9.33 & 5 \\
\hline Total & 100 & & 100 & & 100 & & 100 & \\
\hline
\end{tabular}

Moreover, the informants stated that this criteria shall be equipped with Country factor, they were all agreed that the Country factor has the least significance, and this can be partly explained that the Country factor is only a sub-criterion of the Condition factor, and is applied by [5], as a supplementary to strengthen the housing loan lending processes.

The results in the first phase reveal that the Character factor has the highest impact, followed by Capacity, Collateral, Capital, Condition and Country, respectively (as shown in Table 3). The authors had to find the origins, details and the considerations of each 5Cs criteria.

\section{Second Phase Results}

In the second phase, the informants give the conclusive details for each 5Cs' factor, based on their opinions towards risk factors associated in the housing loan approval. The authors apply the qualitative content analysis to group the similar risk factors (or "Common risks considerations") as well as distinguish their differences (Different risks considerations) of the total risk factors involved in each 5Cs criteria. All details of 5Cs risk factors are tabulated in Table 4. The details are summarised as follows:

\section{Character}

The first phase results pointed that Character is ranked as the highest factor amongst all 5Cs, the informants additionally described 3 common considerations while approving loan, which are 1) Repayment records, 2) Age/Education, and 3) Work experience and position, respectively. However, RCA and CRA added that the Court prosecution records and Borrower's financial status (for example, borrower's account, cash in hand) are also the concern factors in this category. These considerations are mostly regarded as the borrower's internal factors as they are related to the borrower's personal profiles, expenditure, including personal behaviour in repaying loan [11]. 


\section{Capacity}

This factor, representing the abilities to repay housing loan [7] consists of 4 common considerations including1) Borrowers' debt, 2) Salary rate, 3) Stability of income and 4) Tax payment records. MS add the following factors of, namely, Type of business/ revenue /selling amount, the borrower's position in organisation, and the borrower's working skills, whilst RCA mention that the borrower's career/business, which associates with the risky or uncertainty activities (risky career/ business) should be included in the criteria. Therefore, there are 8 considerations in this Capacity factor. Most of them are related to an evaluation of the borrower's personal income, for example, salary rate and position of borrower in organisation, which means the higher position, the higher income that the borrower receives yearly. However, the informants explain that the expenditure and tax payment of the bowers must also be concerned, as the higher personal income, but higher expense, the capacity of repaying loan may be lower than expected [7], [8].

\section{Capital}

The common considerations to look into are borrowers' saving accounts, saving behaviour, burden free assets, and working capital of the borrowers which are necessary in processing the housing loan. Most of the considerations in this Capital factor are related to the borrower's monetary matters. MS and RCA also consider the factors of Capital shares and Sources of capital as they are important for evaluating the loan repayment capacity of juristic person, especially when the borrower lacks Character and Capacity factors.

\section{Collateral}

In the case the borrower does not repay the loan, Thai commercial banks have fully rights to foreclose and liquidate the mortgage properties (the Collateral) as the loan warranty. The Collateral helps mitigate the loss from non-repayment loans. Thus, banks concern on the quality of property's location, such as location and type of properties /assets. However, the mortgaged properties are usually houses or land parcels, the loan assessors therefore consider on the liquidity to sell those foreclosures [7]. The informants also given that the Collateral factor usually enhances the quality of Character and Capacity in the loan approval process [10].

\section{Condition}

As seen in the Table 4, the interviewees pointed that they normally consider on the economic situation at the time of loan application. The Bank of Thailand's rules and regulations towards housing loan and each bank's lending policy are the essential criteria to take into account in the Condition factor. The RCA add the factors concerning current political situation and government policies towards housing, while MS also look at the condition in the borrower's organisation he or she is working with. It is also found that most related factors in this Condition are counted as external factor, or systematic risks factors, which are unpredictable or uncontrollable [12]. [1].

\section{Other factor}

The interviewees also suggested that Thailand Commercial Banks shall concern on the impact of Country risk, (some informants had added this criterion as the sixth $\mathrm{C}$ in the housing loan acquisition criteria), particularly, the expat or foreign borrowers. This factor regards to the original nation of the borrower, the source of funds that the borrower uses to repay the loan, and the international trading environment. This factor is strongly influenced by the political economic and social situation of both borrower and lender's countries [5]. However, this factor has the least significant impact to the overall housing loan process, RCA did not even consider this Country factor into the housing loan approving process. All groups of interviewees state 
that it is difficult to trace the income stream and status of the borrower in the country of origin. Therefore, there are several external risks related to Country factor such as currency exchange rate, economic situation in the country of origin. Nonetheless, it is important to thoroughly analyses when assessing the housing loan to foreigners [13].

Table 4: The consideration factors

\begin{tabular}{|c|c|c|c|c|c|}
\hline \multirow{2}{*}{$\begin{array}{l}5 \mathrm{Cs}^{\prime} \\
\text { Credit }\end{array}$} & \multicolumn{3}{|c|}{ Risk analysis (Risk considerations) } & \multirow{2}{*}{$\begin{array}{l}\text { Common } \\
\text { Factors }\end{array}$} & \multirow{2}{*}{$\begin{array}{l}\text { Different } \\
\text { Factors }\end{array}$} \\
\hline & $\begin{array}{l}\text { Mortgage } \\
\text { Sales (MS) }\end{array}$ & $\begin{array}{c}\text { Retail Credit } \\
\text { Analysis (RCA) }\end{array}$ & $\begin{array}{r}\text { Credit Risk } \\
\text { Analyst (CRA) }\end{array}$ & & \\
\hline \multirow[t]{4}{*}{ Character } & $\begin{array}{l}\text { Repayment } \\
\text { records }\end{array}$ & $\begin{array}{l}\text { Court } \\
\text { prosecution } \\
\text { records }\end{array}$ & $\begin{array}{l}\text { Court } \\
\text { prosecution } \\
\text { records }\end{array}$ & $\begin{array}{l}\text { Repayment } \\
\text { records }\end{array}$ & $\begin{array}{l}\text { Borrowers' financial } \\
\text { status }\end{array}$ \\
\hline & $\begin{array}{l}\text { Working } \\
\text { experience } \\
\text { /position }\end{array}$ & $\begin{array}{l}\text { Borrowers' } \\
\text { financial status }\end{array}$ & $\begin{array}{l}\text { Working } \\
\text { experience and } \\
\text { position }\end{array}$ & $\begin{array}{l}\text { Age } \\
\text { / Educational }\end{array}$ & $\begin{array}{l}\text { Court prosecution } \\
\text { records }\end{array}$ \\
\hline & Age / Educational & $\begin{array}{l}\text { Age / } \\
\text { Educational }\end{array}$ & $\begin{array}{l}\text { Repayment } \\
\text { records }\end{array}$ & $\begin{array}{l}\text { Working } \\
\text { experience } \\
\text { /position }\end{array}$ & \\
\hline & & $\begin{array}{l}\text { Repayment } \\
\text { records }\end{array}$ & $\begin{array}{l}\text { Age/ } \\
\text { Educational }\end{array}$ & & \\
\hline \multirow[t]{5}{*}{ Capacity } & Salary rate & Borrowers' debt & Borrowers' debt & $\begin{array}{l}\text { Borrowers' } \\
\text { debt }\end{array}$ & $\begin{array}{l}\text { Type of business / } \\
\text { revenue / selling } \\
\text { amount }\end{array}$ \\
\hline & Borrowers' debt & Salary rate & Salary rate & Salary rate & Working skills \\
\hline & Position & $\begin{array}{l}\text { Stability of } \\
\text { income }\end{array}$ & $\begin{array}{l}\text { Stability of } \\
\text { income }\end{array}$ & $\begin{array}{l}\text { Stability of } \\
\text { income }\end{array}$ & Position \\
\hline & $\begin{array}{l}\text { Type of business } \\
\text { / revenue /selling } \\
\text { amount }\end{array}$ & $\begin{array}{l}\text { Tax payment } \\
\text { records }\end{array}$ & $\begin{array}{l}\text { Tax payment } \\
\text { records }\end{array}$ & $\begin{array}{l}\text { Tax payment } \\
\text { records }\end{array}$ & $\begin{array}{l}\text { Risky career / } \\
\text { business }\end{array}$ \\
\hline & Working skills & $\begin{array}{l}\text { Risky career / } \\
\text { business }\end{array}$ & & & \\
\hline \multirow[t]{4}{*}{ Capital } & $\begin{array}{l}\text { Bank } \\
\text { saving accounts }\end{array}$ & $\begin{array}{l}\text { Sources } \\
\text { of capital }\end{array}$ & $\begin{array}{l}\text { Bank } \\
\text { saving accounts }\end{array}$ & $\begin{array}{l}\text { Bank saving } \\
\text { accounts }\end{array}$ & Capital shares \\
\hline & Saving behaviours & $\begin{array}{l}\text { Bank saving } \\
\text { accounts }\end{array}$ & Working capital & $\begin{array}{l}\text { Saving } \\
\text { behaviours }\end{array}$ & Sources of capital \\
\hline & $\begin{array}{l}\text { Burden } \\
\text { free assets }\end{array}$ & Working capital & $\begin{array}{l}\text { Burden } \\
\text { free assets }\end{array}$ & $\begin{array}{l}\text { Burden free } \\
\text { assets }\end{array}$ & \\
\hline & Capital shares & $\begin{array}{l}\text { Saving } \\
\text { behaviours }\end{array}$ & & Working capital & \\
\hline \multirow[t]{4}{*}{ Collateral } & Selling liquidity & Selling liquidity & Selling liquidity & $\begin{array}{l}\text { Selling } \\
\text { Liquidity }\end{array}$ & Utilities/Facilities \\
\hline & Location & Location & Location & Location & \\
\hline & $\begin{array}{l}\text { Properties /assets } \\
\text { type }\end{array}$ & $\begin{array}{l}\text { Properties } \\
\text { /assets type }\end{array}$ & $\begin{array}{l}\text { Properties } \\
\text { /assets type }\end{array}$ & $\begin{array}{l}\text { Properties } \\
\text { /assets type }\end{array}$ & \\
\hline & & $\begin{array}{l}\text { Utilities/ } \\
\text { facilities }\end{array}$ & $\begin{array}{l}\text { Utilities/ } \\
\text { facilities }\end{array}$ & & \\
\hline \multirow[t]{3}{*}{ Conditions } & $\begin{array}{l}\text { Current economic } \\
\text { situation (while } \\
\text { borrowing) }\end{array}$ & $\begin{array}{l}\text { Bank of Thailand } \\
\text { regulations } \\
\text { towards housing } \\
\text { loans }\end{array}$ & $\begin{array}{l}\text { Bank of Thailand } \\
\text { regulations } \\
\text { towards housing } \\
\text { loans }\end{array}$ & $\begin{array}{l}\text { Current } \\
\text { economic } \\
\text { situation }\end{array}$ & $\begin{array}{l}\text { Borrower's personal } \\
\text { profiles } \\
\text { (organisation) }\end{array}$ \\
\hline & $\begin{array}{l}\text { Borrower's } \\
\text { personal profiles } \\
\text { (organisation) }\end{array}$ & $\begin{array}{l}\text { Current } \\
\text { economic } \\
\text { situation }\end{array}$ & $\begin{array}{l}\text { Current } \\
\text { economic } \\
\text { situation }\end{array}$ & $\begin{array}{l}\text { Bank of } \\
\text { Thailand } \\
\text { regulations } \\
\text { towards } \\
\text { housing } \\
\text { loans }\end{array}$ & $\begin{array}{l}\text { Government policies } \\
\text { towards housing }\end{array}$ \\
\hline & & $\begin{array}{l}\text { Government } \\
\text { policies towards } \\
\text { housing }\end{array}$ & & & \\
\hline
\end{tabular}


Khumpaisal, S., Meechai, W., \& Bunnag, K. (2017). An Investigation of Risks Factors affect to Housing Loan's Processes in Thailand Commercial Banks. Archives of Business Research, 5(8), 40-49.

\begin{tabular}{|c|c|c|c|c|c|}
\hline \multirow{2}{*}{$\begin{array}{l}5 \mathrm{Cs}^{\prime} \\
\text { Credit }\end{array}$} & \multicolumn{3}{|c|}{ Risk analysis (Risk considerations) } & \multirow{2}{*}{$\begin{array}{l}\text { Common } \\
\text { Factors }\end{array}$} & \multirow{2}{*}{$\begin{array}{l}\text { Different } \\
\text { Factors }\end{array}$} \\
\hline & $\begin{array}{c}\text { Mortgage } \\
\text { Sales (MS) }\end{array}$ & $\begin{array}{r}\text { Retail Credit } \\
\text { Analysis (RCA) }\end{array}$ & $\begin{array}{r}\text { Credit Risk } \\
\text { Analyst (CRA) }\end{array}$ & & \\
\hline \multirow[t]{4}{*}{$\begin{array}{l}\text { Other } \\
\text { factors }\end{array}$} & $\begin{array}{l}\text { Tax Payment } \\
\text { records }\end{array}$ & $\begin{array}{l}\text { Tax Payment } \\
\text { records }\end{array}$ & $\begin{array}{l}\text { Actually } \\
\text { consider on } \\
\text { capital, } \\
\text { collateral, } \\
\text { and condition of } \\
\text { each } \\
\text { borrower. }\end{array}$ & $\begin{array}{l}\text { Tax Payment } \\
\text { records }\end{array}$ & $\begin{array}{l}\text { Currency exchange } \\
\text { rate }\end{array}$ \\
\hline & $\begin{array}{l}\text { Type of career/ } \\
\text { job }\end{array}$ & $\begin{array}{l}\text { Type of career/ } \\
\text { job }\end{array}$ & & $\begin{array}{l}\text { Type of career } \\
\text { /job }\end{array}$ & Guarantor \\
\hline & $\begin{array}{l}\text { Currency } \\
\text { exchange rate }\end{array}$ & Guarantor & & & $\begin{array}{l}\text { The borrower's } \\
\text { country economic } \\
\text { situation }\end{array}$ \\
\hline & & $\begin{array}{l}\text { The borrower's } \\
\text { country } \\
\text { economic } \\
\text { situation }\end{array}$ & & & $\begin{array}{l}\text { Actually consider on } \\
\text { capital, collateral, } \\
\text { and condition of } \\
\text { each borrower }\end{array}$ \\
\hline
\end{tabular}

\section{CONCLUSIONS AND RECOMMENDATIONS}

According to our results, Thailand largest 5 commercial banks concern on the default of housing loans, and each bank has its own techniques to analyse and assess the credit risk of the borrowers. However, there are some non-synchronized between each technique, because of these assessors had developed the assessment technique/criteria based on their own individual perspectives and experiences, by the Banks' policies towards loan acquisitions, or by the borrowers' records.

In addition, these techniques may not suit with the current situation of housing loan approving process, whether in conditional or policy terms. As the defaults in housing loan may occur by several reasons, such as market factors, business management etc., which would devalue the banks' liquidity, reputation and essentially the bank's capital. This paper also states that Thai commercial banks must concentrate on the importance of credit risk management processes (identification, assessment, treatment and monitoring/controlling), before making decision toward housing loan approval.

A prioritization of risks associated in housing loan approval was developed in this paper, it indicates that $5 \mathrm{Cs}$ criteria shall be extended while considering the borrower's potential to repay loan. The priority of $5 \mathrm{Cs}$ is ranked as Character, Capacity, Collateral, Capital, and Condition, respectively, and the sub-criteria that shall be included in 5Cs are also described in second phase results. To assess the borrower's credit risks effectively, the authors recommend that Thai commercial banks shall apply other tools/techniques such as Credit Scoring, Know Your Customer: KYC, or Customer Due Diligence : CDD, together with 5Cs, these will help in classifying the borrower's potential and likelihood to default.

In addition, the banks shall provide a comprehensive and continuously trainings for the decision makers, risk assessors and relevant staff in order to update the current economic/political situation, as well as to acknowledge all new conditions issued by banks or other regulators 


\section{References}

Khumpaisal, S., An Examination of Economic Risks' Perception of Thai Real Estate Developers. International Journal of Trade, Economics and Finance. , 2015. 6 (3): p. 14-21.

Bank for International Settlement: BIS, Principles for the Management of Credit Risk, Basel Committee on Banking Supervision. Available on www.http://www.bis.org/publ/bcbs75.pdf, 2000. retrieved 20th January 2017

International Monetary Fund: IMF., Compilation Guide on Financial Soundness Indicators. Available on https://www.imf.org/external/np/sta/fsi/eng/2004/guide/index.htm.,, 2004. retrieved 15th February, 2017.

Maenig, M., Size and Impact of Real Estate Sector and Its Role for Business Cycles and Growth, Understanding German Real Estate Markets, Management for Professional, Berlin Heidelberg, Germany: Springer-Verlag, 2012 . p. 19-25

Bank of Thailand: BOT., Bank of Thailand Annual Report 2014 Available https:// www.bot.or.th /English/ResearchAndPublications/Report/Pages/default.aspx., retrieved 15 ${ }^{\text {th }}$ February, 2017.

Meechai, W., Khumpaisal, S., and Bunnaga, K., Housing loans' Credit Risks Factors in Thailand Commercial Banks, in The $2^{\text {nd }}$ International Conference on Management, Finance, and Economics (ICMFE), 2016 Proceedings. Pattaya, Thailand, $9^{\text {th }}-10^{\text {th }}$ July, 2016.

Pittiyavivit, C., Financial Market in Thailand, Bangkok, Thailand, Amarin Printing Group, 2007

Well Fargo, Know what Lenders look for, Available https://www.wellsfargo.com/financial-education /creditmanagement/five-c/ retrieved 23rd March, 2017.

US Dept. of Commerce, 5Cs of Credit Analysis, Minority Business Development Agency website, Available https://www.mbda.gov/news/blog/2010/08/5-cs-credit-analysis retrieved 23rd March, 2017.

Massachusetts Land Trust, Working Definitions of Key Financing Terms, the Conservation Fund, Massachusetts Land Trust, Sudbury, Massachusetts. USA, 2016, p.1-4

Wilcox, E.W., WHAT QUALIFIES YOU FOR CREDIT? The Six “C's" of Credit, CBM Credit Education Foundation, Madison, Wisconsin, United States of America. Avalable: www.cbmfoundation.org/downloads/qualifies_you_credit.pdf. 2016, retrieved 23rd March, 2017.

Hargitay, S., and Yu, S.M., Decision criteria - return and risk, Property Investment Decisions: A quantitative Approach, 1993 London, UK. E\& FN Spon, p. 37-38

Pichitchumpon, K., Factors that Affect to the Consideration of Financial Institutions in Granting a credit to Small and Medium Enterprises (SMEs), in The 3rd Annual PSU Phuket International Conference 2014, 13 th -November 14, 2014, Proceedings, Phuket, Thailand 